:Kafr El-Sheikh Vet. Med. J. Vol. 1 No. 1 (2003) (331-343)

\title{
FURTHER STUDIES ON THE PREVALENCE OF SUBCLINICAL MASTITIS IN DAIRY COWS IN EL-GHARBIA AND KAFR EL-SHEIKH GOVERNORATES WITH SPECIAL OBSERVATION TO ANTIBIOTIC SENSITIVITY
}

\author{
1. I. Al-Hawary; Azza, M.K .Sobeih and 1. Aman \\ Dept. of Food Hygiene, Fac. Vet. Med. Kafr El-Sheikh. Tanta Univ.
}

\begin{abstract}
A total of 1136-quarter cow's milk samples were collected from apparently healthy cow's from 2 dairy farms in El Gharbia and 3 dairy farms in Kafr El-Sheikh Governorates (Egypt). All samples were screened for subclinicl mastitis using California Mastitis Test (CMT), Somatic Cell Count (SCC), lactose and chloride content. All Positive CMT samples were examined microbiologically for isolating the most causative microbial agents of subclinical mastitis. 136 (22.5\%) samples collected from El-Gharbia Governorate were positive for CMT .Of them 100 samples $(73.5 \%)$ scored $2+$ and 36 (26.5\%) scored 3+; 120 (20\%) contained lactose below 4.7\% and 140 (23.2\%) had chloride content greater than 0.14\%. While 65 (12.2\%) quarter milk samples collected from Kafr El-Sheikh farms were CMT positive, of them 24 (36.9\%) samples scored 2+ and 41(63.1\%) samples scored 3+ ; $72(13.5 \%)$ samples contained lactose less than $4.7 \%$ and 119 (22.4\%) had chloride content greater than $0.14 \%$.

Infectious organisms isolated from CMT positive samples were Coliforms (88.2\%), Staphylococci (26.5\%) and E-coli (14.7\%) while both coagulase +ve Staph. aureus and Strept. agalactiae failed to be detected from El-Gharbia quarter samples. On the other hand Coliforms, Staphylococci, coagulase $+v$ Staph. aureus, E-coli and Strept agalactiae were isolated with a percentages ranging from 1.5 to $52.3 \%$ from Kafr El-Sheikh samples. Somatic cell count (SCC) ranged from >105 to $<107$ 'e in vitro sensitivity pattern of the
\end{abstract}


isolated organisms against 7 antibiotics was tested. Flumequin and Gentamycin gave the best results in inhibiting all the tested Staph. aureus, E-coli and Strept. agalactiae tested strains. It is concluded that subclinical mastitis in dairy cows is a serious problem in the surveyed area.

\section{INTRODUCTION}

Production of high quality milk in dairy farms depends essentially on minimizing bacteria and excluding chemical contaminants (Pankey, 1989). It also requires healthy dairy animals which are the result of many management factors including mastitis control and herd health programs (Bodman et.al., 1988; Ibtisam, et al. 1995 ). Mastitis has a significant impact on the economics of milk production and consumer health specially in small private farms in developing countries where hygienic measures and milking sanitation are often insufficient(Ramachandrainh, et. al., 1990; Zatoun and Manaa, 1992 and Omyma Saleh. 1999).

Over 200 different organisms have been recorded in scientific literature as being causes of bovine mastitis the common pathogens were contagious bacteria which spread from infected quarters to other quarters as Streptococcus agalactiae and Staphylococcus aureus. Moreover, environmental bacteria that are commonly present in the cows environment may reach the teat orifices as E-coli and other groups of coliforms and Enterobacter species (Hogan, et.al. 1986; Refai, 1988; Saeman et al., 1988 and Blowey \& Edmondson, 1995).

Due to the insufficient dosage in intra-mammary administration of antibiotics or non indicated application of dry cow therapy the development of antibiotic resistance strains of bacteria resembles a consumer risk as the responsibility of the veterinarian for consumers health is the major topic of importance (Mahmoud, 1988).

Therefore, this study was conducted to determine the subclinical mastitis in cows over a 12 weeks study period and to assess the resistance of the causative bacteria to selected antibiotic agents.

$\overline{\overline{\text { Kafr El-Sheikh Vet.Med.J. Vol. } 1 \text { No.1 (2003) }}}$ 


\section{MATERIALS \& METHODS}

This study was carried out in five semi- intensively arranged farms at El-Gharbia (i, ii) and Kafr El-Sheikh (iii, iv, v) Governorates. Each farm was visited once weekly for a 12-week period. A total of 1136 quarter milk samples (100 ml each) from cows in early and mid lactation period were selected and examined as follows: -

All quarter milk samples were subjected to California Mastitis Test (CMT) to detect subclinical mastitis quarters as described by $\boldsymbol{A P H} \boldsymbol{A}$, (1993). Reaction of $2+$ or higher were considered as evidence of subclinical mastitis.

Films were prepared from composite milk samples $(25 \mathrm{ml}$ of milk were pooled from the four quarters of each selected cow for somatic cells count (SCC)as described by $\boldsymbol{A P H A}(1993)$. Chloride content was determined according to Atherton and Newlander (1977). Isolation and identification of coliforms, E.coli, Streptococcus agalactiae and Staphylococcus aureus were carried out according to $\boldsymbol{A P H A . ~ ( 1 9 9 3 ) ~ a n d ~}$ Bailey and Scott., (1994).

Antibiotic sensitivity tests were performed on Staphylococcus auerus, E.coli and Streptococcus agalactiae isolates. The following antimicrobial agents with respective disc potency $(\mathrm{mg})$ were used: Gentamycin (10 mg), Neomycin (30 mg), Flumequine, Amoxacillin (25 $\mathrm{mg}$ ), Oxyteteracyclin (30 mg). Cloxacillin (5 mg) and Penicillin (10 I.U.) according to the method adopted by Hirsh and Zee (1999).

\section{RESULTS \& DISCUSSION}

Table(1): Chemical parameters of quarter milk samples collected from two Farms in El-Gharbia Governorate:

\begin{tabular}{|c|c|c|c|c|c|c|c|}
\hline \multirow{2}{*}{$\begin{array}{c}\text { Source of } \\
\text { samples }\end{array}$} & \multirow{2}{*}{$\begin{array}{c}\begin{array}{c}\text { No. of } \\
\text { examined } \\
\text { samples }\end{array} \\
\end{array}$} & \multirow{2}{*}{$\begin{array}{c}\text { CMT +ve } \\
\text { samples }\end{array}$} & \multicolumn{2}{|c|}{$\begin{array}{c}\text { California Mastitis Test } \\
\text { (CMT) }\end{array}$} & \multirow{2}{*}{$\begin{array}{l}\text { Somatic cell } \\
\text { count }\end{array}$} & \multirow{2}{*}{$\begin{array}{c}\text { Lactose } \\
<4.7 \%\end{array}$} & \multirow{2}{*}{$\begin{array}{l}\text { Chlorine } \\
>0.14 \%\end{array}$} \\
\hline & & & $2+$ & $3+$ & & & \\
\hline Farm i & 204 & $\begin{array}{c}49 \\
(24 \%)^{*}\end{array}$ & $\begin{array}{c}33 \\
(67.3 \%)^{* *}\end{array}$ & $\begin{array}{c}16 \\
(32.7 \%)\end{array}$ & \multirow{3}{*}{$>10^{5}$ to $<10^{7}$} & $\begin{array}{c}55 \\
(27 \%)^{*}\end{array}$ & $\begin{array}{c}60 \\
(29.4 \%)^{*}\end{array}$ \\
\hline Farm ii & 400 & $\begin{array}{c}87 \\
(21.8 \%)\end{array}$ & $\begin{array}{c}67 \\
(77 \%)\end{array}$ & $\begin{array}{c}20 \\
(23 \%)\end{array}$ & & $\begin{array}{c}65 \\
(16.3 \%)\end{array}$ & $\begin{array}{c}80 \\
(20 \%)\end{array}$ \\
\hline Total & 604 & $\begin{array}{c}136 \\
(22.5 \%)\end{array}$ & $\begin{array}{c}100 \\
(73.5 \%)\end{array}$ & $\begin{array}{c}36 \\
(26.5 \%)\end{array}$ & & $\begin{array}{l}120 \\
(20 \%)\end{array}$ & $\begin{array}{c}140 \\
(23.2 \%)\end{array}$ \\
\hline
\end{tabular}

$\overline{\overline{\text { Kafr El-Sheikh Vet.Med.J. Vol. } 1 \text { No.1 (2003) }}}$ 
Table(2):Chemical parameters of quarter milk samples collected from three Farms in Kafr El-Sheikh Governorate:

\begin{tabular}{|c|c|c|c|c|c|c|c|}
\hline \multirow{2}{*}{$\begin{array}{l}\text { Source of } \\
\text { samples }\end{array}$} & \multirow{2}{*}{$\begin{array}{c}\text { No. of } \\
\text { examined } \\
\text { samples }\end{array}$} & \multirow{2}{*}{$\begin{array}{c}\text { CMT } \\
\text { +ve } \\
\text { samples }\end{array}$} & \multicolumn{2}{|c|}{$\begin{array}{c}\text { California Mastitis } \\
\text { Test (CMT) } \\
\end{array}$} & \multirow{2}{*}{$\begin{array}{l}\text { Somatic cell } \\
\text { count }\end{array}$} & \multirow{2}{*}{$\begin{array}{l}\text { Lactose } \\
<4.7 \%\end{array}$} & \multirow{2}{*}{$\begin{array}{l}\text { Chlorine } \\
>0.14 \%\end{array}$} \\
\hline & & & $2+$ & $3+$ & & & \\
\hline Farm iii & 152 & $\begin{array}{c}12 \\
(7.9 \%)^{*}\end{array}$ & $\begin{array}{c}3 \\
(25 \%)^{* *}\end{array}$ & $\begin{array}{c}9 \\
(75 \%)\end{array}$ & \multirow{4}{*}{$>10^{5}$ to $<10^{7}$} & $\begin{array}{c}15 \\
(9.9 \%)^{*}\end{array}$ & $\begin{array}{c}25 \\
(16.4 \%)^{*}\end{array}$ \\
\hline Farm iv & 200 & $\begin{array}{c}29 \\
(14.5 \%)\end{array}$ & $\begin{array}{c}12 \\
(41.4 \%)\end{array}$ & $\begin{array}{c}17 \\
(58.6 \%)\end{array}$ & & $\begin{array}{c}50 \\
(25 \%)\end{array}$ & $\begin{array}{c}54 \\
(27 \%)\end{array}$ \\
\hline Farm v & 180 & $\begin{array}{c}24 \\
(13.3 \%) \\
\end{array}$ & $\begin{array}{c}9 \\
(37.5 \%) \\
\end{array}$ & $\begin{array}{c}15 \\
(62.5 \%) \\
\end{array}$ & & $\begin{array}{c}7 \\
(3.9 \%) \\
\end{array}$ & $\begin{array}{c}40 \\
(22.2 \%) \\
\end{array}$ \\
\hline Total & 532 & $\begin{array}{c}65 \\
(12.2 \%)\end{array}$ & $\begin{array}{c}24 \\
(36.9 \%)\end{array}$ & $\begin{array}{c}41 \\
(63.1 \%)\end{array}$ & & $\begin{array}{c}72 \\
(13.5 \%)\end{array}$ & $\begin{array}{c}119 \\
(22.4 \%)\end{array}$ \\
\hline
\end{tabular}

* From the total sampls

**from the CMT +ve sampls

Table(3):Incidence of causative organisms in subclinically affected quarter milk samples collected from El-Gharbia farms.

\begin{tabular}{|c|c|c|c|c|c|c|c|}
\hline \multirow[b]{2}{*}{ Farms } & \multirow{2}{*}{$\begin{array}{c}\text { No. of } \\
\text { Examined } \\
\text { samples }\end{array}$} & \multirow{2}{*}{$\begin{array}{c}\text { No. of } \\
\text { +ve } \\
\text { samples }\end{array}$} & \multicolumn{5}{|c|}{ Causative organisms } \\
\hline & & & Coliforms & E-coli & $\begin{array}{c}\text { Strept. } \\
\text { agalactia }\end{array}$ & Staphylococci & $\begin{array}{l}\text { Coagulase+ve } \\
\text { Staph.aureus } \\
\end{array}$ \\
\hline Farm I & 204 & $\begin{array}{c}49 \\
(24 \%)^{*}\end{array}$ & $\begin{array}{c}39 \\
(79.6 \%)^{* *}\end{array}$ & $\begin{array}{c}7 \\
(14.3 \%)\end{array}$ & 0 & $\begin{array}{c}12 \\
(24.5 \%)\end{array}$ & 0 \\
\hline Farm ii & 400 & $\begin{array}{c}87 \\
(21.7 \%) \\
\end{array}$ & $\begin{array}{c}81 \\
(93.1 \%) \\
\end{array}$ & $\begin{array}{c}13 \\
(14.9 \%) \\
\end{array}$ & 0 & $\begin{array}{c}24 \\
(27.6 \%) \\
\end{array}$ & 0 \\
\hline Total & 604 & $\begin{array}{c}136 \\
(22.5 \%)\end{array}$ & $\begin{array}{c}120 \\
(88.2 \%)\end{array}$ & $\begin{array}{c}20 \\
(14.7 \%)\end{array}$ & 0 & $\begin{array}{c}36 \\
(26.5 \%)\end{array}$ & 0 \\
\hline
\end{tabular}

* \% From examind sampls

$* * \%$ Of the organisms calculated from the positive samples

Table(4):Incidence of causative organisms in subclinically affected quarter milk samples collected from Kafr El-Sheikh farms:

\begin{tabular}{|c|c|c|c|c|c|c|c|}
\hline \multirow[b]{2}{*}{ Farms } & \multirow{2}{*}{$\begin{array}{c}\text { No. of } \\
\text { Examined } \\
\text { samples }\end{array}$} & \multirow[b]{2}{*}{$\begin{array}{c}\text { No. of +ve } \\
\text { samples }\end{array}$} & \multicolumn{5}{|c|}{ Causative organisms } \\
\hline & & & Coliforms & E-coli & Strept.agalactia & Staphylococci & $\begin{array}{r}\text { Coagulase +ve } \\
\text { Staph.aureus }\end{array}$ \\
\hline Farm iii & 152 & $\begin{array}{c}12 \\
(7.9 \%)^{*}\end{array}$ & $\begin{array}{c}5 \\
(41.7 \%)^{* *}\end{array}$ & $\begin{array}{c}1 \\
(8.3 \%)\end{array}$ & 0 & $\begin{array}{c}7 \\
(58.3 \%)\end{array}$ & $\begin{array}{c}6 \\
(50 \%)\end{array}$ \\
\hline Farm iv & 200 & $\begin{array}{c}29 \\
(14.5 \%)\end{array}$ & $\begin{array}{c}16 \\
(55.2 \%)\end{array}$ & $\begin{array}{c}2 \\
(6.9 \%) \\
\end{array}$ & $\begin{array}{c}1 \\
(3.4 \%)\end{array}$ & $\begin{array}{c}13 \\
(44.8 \%)\end{array}$ & $\begin{array}{c}7 \\
(24.1 \%) \\
\end{array}$ \\
\hline Farm v & 180 & $\begin{array}{c}24 \\
(13.3 \%)\end{array}$ & $\begin{array}{c}13 \\
(54.2 \%)\end{array}$ & $\begin{array}{c}1 \\
(4.2 \%)\end{array}$ & 0 & $\begin{array}{c}9 \\
(37.5 \%)\end{array}$ & $\begin{array}{c}6 \\
(25 \%)\end{array}$ \\
\hline Total & 532 & $\begin{array}{c}65 \\
(12.2 \%)\end{array}$ & $\begin{array}{c}34 \\
(52.3 \%)\end{array}$ & $\begin{array}{c}4 \\
(6.2 \%)\end{array}$ & $\begin{array}{c}1 \\
(1.5 \%)\end{array}$ & $\begin{array}{c}29 \\
(44.6 \%)\end{array}$ & $\begin{array}{c}19 \\
(29.2 \%)\end{array}$ \\
\hline
\end{tabular}

* \% From examind sampls

$\overline{\text { Kafr El-Sheikh Vet.Med.J. Vol. } 1 \text { No.1 (2003) }}$ 
$* * \%$ Of the organisms calculated from the positive samples

Table(5):Antibiotics sensitivity of the isolated strains from quarter milk samples

\begin{tabular}{||c||c||c|c||c|c||c|c||}
\hline \multicolumn{2}{|c||}{ Antibiotic used } & \multicolumn{2}{c||}{ Staph.aureus (n=19) } & \multicolumn{2}{c||}{ E.coli (n=24) } & \multicolumn{2}{c|}{ St.agalactia (n=1) } \\
\hline \hline & Amount & No & \% & No & \% & No & \% \\
\hline \hline A & $20 \mathrm{Mg}$ & 0 & 0 & 2 & 8.3 & 0 & 0 \\
\hline $\mathbf{C}$ & $5 \mathrm{Mg}$ & 15 & 78.9 & 0 & 0 & 0 & 0 \\
\hline $\mathbf{F}$ & $30 \mathrm{Mg}$ & 19 & 100 & 24 & 100 & 1 & 100 \\
\hline $\mathbf{G}$ & $10 \mathrm{Mg}$ & 19 & 100 & 24 & 100 & 0 & 0 \\
\hline $\mathbf{N}$ & $10 \mathrm{Mg}$ & 8 & 42.1 & 3 & 12.5 & 0 & 0 \\
\hline $\mathbf{O}$ & $30 \mathrm{Mg}$ & 16 & 84.2 & 4 & 16.7 & 0 & 0 \\
\hline $\mathbf{P}$ & $\mathrm{I.U}$ & 13 & 68.4 & 0 & 0 & 0 & 0 \\
\hline \hline
\end{tabular}

$\mathrm{A}=$ Amoxcillin

$\mathrm{O}=$ Oxytetracyclin

$\mathrm{G}=$ Gentamycin
$\mathrm{N}=$ Neomycin

$\mathrm{F}=$ Flumequine
$\mathrm{C}=$ Cloxacillin

$\mathrm{P}=$ Penicillin
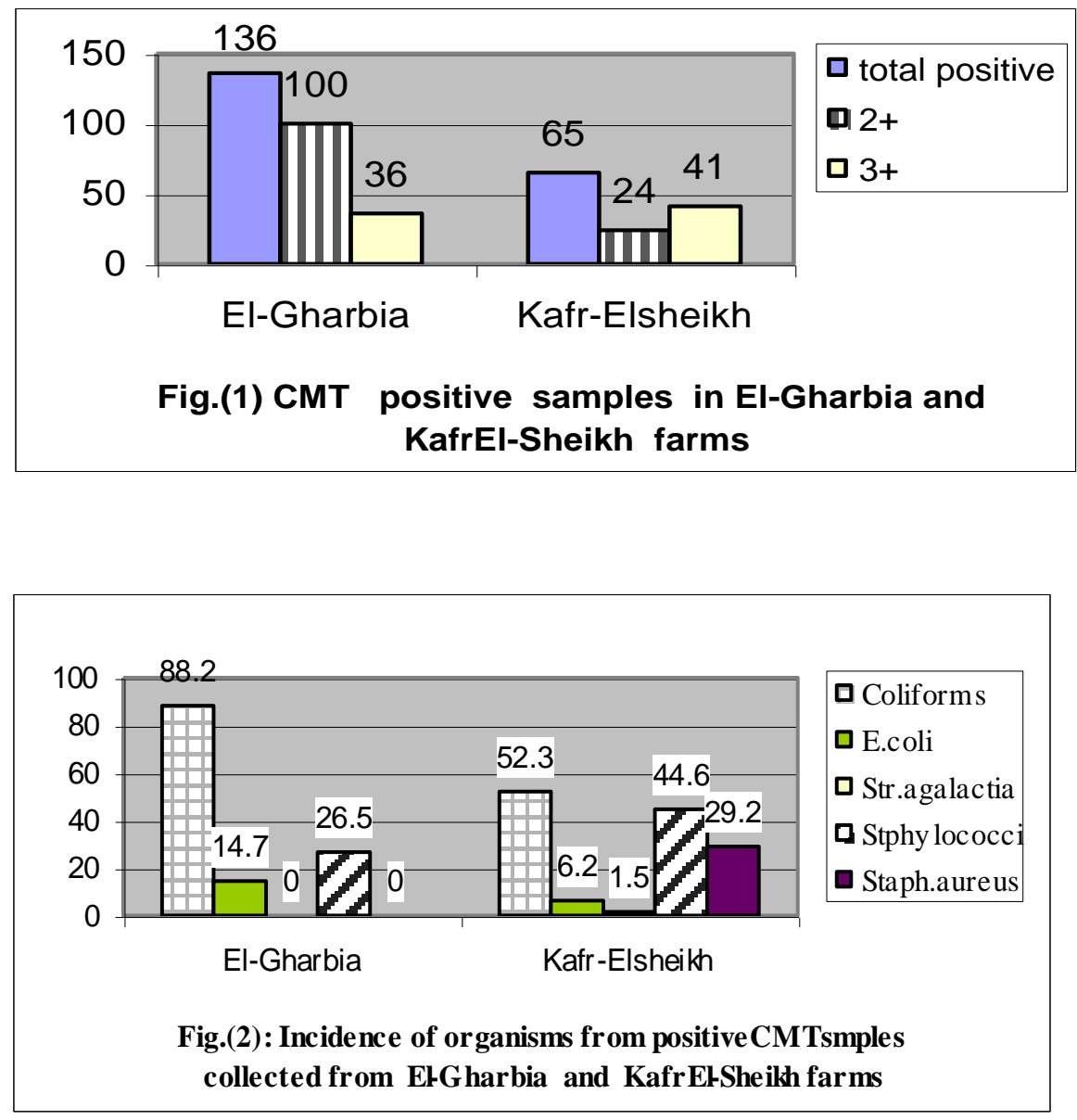

$\overline{\text { Kafr El-Sheikh Vet.Med.J. Vol. } 1 \text { No.1 (2003) }}$ 
Assessment of high quality milk demonstrated by reductions of the levels of subclinical mastitis, as determined by the individual levels of somatic cell and chemical and bacteriological examinations.

\section{Chemical examinations:-}

Table (1) and Fig. (1) show that out of 604 quarter milk samples collected from El-Gharbia farms (i,ii), 136 (22.5\%) gave positive results with CMT of them $100(73.5 \%)$ scored 2+ve and 36 (26.5\%) scored 3+. In farm i,33 samples scored 2+ and 16 samples scored 3+ with CMT,Vs 67 and 20 samples scored $2+$ and $3+$ in farm ii. On the other hand, 65 (12.2\%) samples out of 532 quarter milk samples collected from three farms (iii,iv,v) in Kafr El-Sheikh gave positive with CMT of them 24 (36.9\%) scored 2+ve and $41(63.1 \%)$ scored 3+ve. In farm iii, three $(25 \%)$ showed score $2+\mathrm{ve}$ and $9(75 \%)$ had score $3+\mathrm{ve} . \mathrm{Vs} 12(41.4 \%) \& 9$ $(37.5 \%)$ scored $2+v e$ and $17(58.6 \%) \& 15(62.5 \%)$ scored $3+v e$ with CMT in farm iv \& v respectively (Table, 2 and Fig.1).

The obtained results were higher than that recorded by El-Kholy \& Hosein (1990) and Ahmed \& Azza Deeb (2001), while the results were lower than that reported by Patil et al., (1995). Nazem and Azab (1998) reported that the sensitivity of CMT was $88.02 \%$. The variation between the incidence of subclinical mastitis in this study and other authors can be attributed to several factors including the rate of exposure of animals to infection and the hygienic conditions.

Herd consistently producing milk bulk milk somatic cell counts (BMSCC) less than 2x105 cells/ $\mathrm{ml}$ are common. In the major dairy producing countries of the world the standards for the upper legal threshold of BMSCC are currently at $4 \times 105$ cells $/ \mathrm{ml}$ within the European union $5 \times 105$ cells $/ \mathrm{ml}$ in Canada and $7.5 \times 105$ cells $/ \mathrm{ml}$ in the United States (Larry Smith and Hogan, 1996).

Our study declared that the CMT positive samples had SCC from $>105$ to $<107 / \mathrm{ml}$ in composite milk milk obtained from El- Gharbia and Kafr El-Sheikh farms (tables 1\&2).Higher counts than the legal requirements of European union were recorded while within the legal of $\overline{\overline{\text { Kafr El-Sheikh Vet.Med.J. Vol. } 1 \text { No.1 (2003) }}}$ 
Canadian and the United States standards. Nearly si recorded by Ahmed and Deeb (2001), while higher results were reported by Abou- Zaid and El-Sawalhy (1999).

There is no clear threat to human health from SCC in excess to $4 \times 105 \mathrm{cell} / \mathrm{ml}$ and the cell count of milk has long been regarded as a measure of the quality of milk produced by herd (Booth,1996). High BMSCC are caused by individual cows with high SCC as cows suffering from physiological disturbance or pathological udder damage also newly calved cow or drying off may lead to high SCC, subclinical mastitis caused by infectious germs is the most important cause of high BMSCC (Logan and Gillespie, 1996).

The examination of lactose content reveals that 120 (20\%) samples collected from El- Gharbia farms recorded lactose \% less than 4.7, 55 $(27 \%)$ samples in farm i and $65(16.3 \%)$ in farm ii. On the other hand, 72 (13.5\%) samples collected from Kafr El-Sheikh farms had $<4.7 \%$ lactose out of them $15(9.9 \%)$ in farm iii,50 (25\%) in farm iv and $7(3.9 \%)$ in farm $\mathrm{v}$ (Table 1,2). In mastitic cases, lactose sharply decreases and chloride percentage increases to maintain the osmotic pressure inside the inflamed quarters.

Results in Table 1 \& 2 show that 140 (23.2\%) milk samples collected from El-Gharbia farms, $60(29.4 \%)$ in farm i and $80(20 \%)$ in farm ii, contained $>0.14 \%$ while for milk samples collected from Kafr El-Sheikh farms 119 (22.4\%) contained chloride greater than $0.14 \%, 25$ $(16.4 \%)$ of them in farm iii, $54(27 \%)$ in farm iv and $40(22.2 \%)$ in farm v. Lower results were obtained by Ahmed and Azza Deeb (2001) while higher results were recorded by Azza Deeb (1996). The higher results my be attributed to the entrance of sodium chloride from blood to the udder suffering from mastitis leading to increase of chloride above normal (Atherton and Newlander, 1977).

\section{Microbiological Examination:}

The most frequently organisms isolated from CMT positive samples collected from El- Gharbia Governorate were coliforms from

$\overline{\text { Kafr El-Sheikh Vet.Med.J. Vol. } 1 \text { No.1 (2003) }}$ 
$39(79.6 \%)$ in farm i and $81(93.1 \%)$ in farm ii. While E.coli were isolated from 20 (14.7\%) quarter milk samples $7(14.3 \%)$ in farm i and 13 (14.9\%)in farm ii (Table,3 and Fig.,2). On the other hand, coliforms were detected in $34(52.3 \%)$ subclinically affected quarter milk samples collected from Kafr El-Sheikh farms, 5 (41.7\%) in farm iii, $16(55.2 \%)$ in farm iv and $13(54.2 \%)$ in farm v, E-coli were isolated from $4(6.2 \%)$ of examined quarter milk samples, $1(8.3 \%)$ in farm iii,2 (6.9\%) in farm iv and 1 (4.2\%) in farm v (Table,4 and Fig.2). Regarding E-coli higher results were obtained by Schukken et al., (1989); Nazem \& Azab (1998) and Ahmed \& Azza Deeb (2001), while nearly similar results were reported by Tawfik et al., (1984) and Omyma Saleh (1999).

Coliform infections are considered to be the major cause of environmental mastitis (Anderson, 1989 and Larry Smith \& Hogan ,1993) . Larry Smith et.al., (1985) estimated that 30 to $40 \%$ of all cases of clinical mastitis were caused by coliform bacteria and the most commonest of these organisms were E-coli.

Streptococcus agalactiae arganisms failed to be isolated from all quarter milk samples collected from El-Gharbia farms while they were isolated from only one sample $(1.5 \%)$ of the examined quarter milk samples collected from Kafr El-Sheikh farms (Table 3 ,4 Fig. ,2). AbouZaid \& El-Sawalhy (1999) obtained nearly similar results, while higher results were obtained by Nazem \& Azab (1998) and Ahmed\& Azza Deeb (2001).

Staphylococci were clearly observed in $36(26.5 \%)$ quarter milk samples collected from El-Gharbia farms, $12(24.5 \%)$ in farm i and 24 $(27.6 \%)$ in farm ii (Table, 3 and Fig., 2 ). On the other hand , 29 (44.6\%) samples collected from Kafr El-Sheikh Governorate had Staphylococci, $7(58.3 \%)$ in farm iii, $13(44.8 \%)$ in farm iv and $9(37.5 \%)$ in farm v, (Table, 4 and Fig. , 2 ).

Coagulase +ve Staphylococcus aureus failed to be detected in all the examined samples collected from El-Gharbia farms, while it was detected in 19 (29.2\%) quarter milk samples collected from Kafr El-

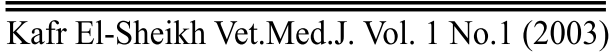



al., (1984); Nazem \& Azab (1998) and Ahmed \& Azza Deeb (2001).

Staphylococcus aureus is one of the major pathogenic causes of intramamary infection, field experience suggests that Staphylococcus aureus can persist for long periods in the herd with relatively low clinical or SCC problems but with high prevalence (Nickerson, 1993 and Gaddo et al., 1996).

Wilson,et.al.,(1994)reported that mastitis caused by Staphylococcus aureus was present in $78.7 \%$ of dairy herd in north eastern United States, while Logan \& Gillespie (1996) found that the commonest bacteria isolated from subclinical mastitis were Staphylococci which were found in $98 \%$ of herds and Streptococcus agalctiae in $20 \%$ of herds.

Regarding at the sensitivity of the isolated microorganism to certain antibiotics, using seven different antibiotics to 19 strain of Staphylococcus aureus, 24 strain of E-coli and one strain of Streptococcus agalactiae (Table,5). All the isolated strains were sensitive to flumequine and gentamycin. Similarly the higher sensitivity of all isolates of E-coli to gentamycin had earlier been reported by Ngeleka, et. al., (1998). While $42.1 \%$ of the Staph. aureus isolates and $12.5 \%$ of the E-coli isolates appear to be sensitive to neomycin .The prevalence of resistance of Staph. aureus and E-coli isolates to amoxycillin were $100 \%$ and $8.3 \%$ respectively. On the other hand, $84.2 \%$ and $16.7 \%$ Staph. aureus and Ecoli isolates were sensitive to oxytetracycline respectively .The Staph. aureus isolates were sensitive to cloxacillin and penicillin antimicrobials with a percentages of $78.9 \%$ and $68.4 \%$ respectively, while all $(100 \%)$ Ecoli isolates were resistant to them. The superior effect of Flumequin than other antibiotics might be due to the fact that Flumequin seldom used as a treatment for mastitis in contrast to other antibiotics which most frequently used and may leads to the development of resistant strains.

The resistance behaviour of $100 \%$ each Staph. aureus , and $91.75 \%$ E.coli and $100 \%$ Strept. agalactiae strains to Amoxycillin may developed Kafr El-Sheikh Vet.Med.J. Vol. 1 No.1 (2003) 
tment of mastitis, Penicillin resistance

among E.coli and Staph.aureus isolates may be due to the development of B-lactomase from Penicillin- binding protein of the bacterial cell wall. In Germany, Belgium, England and Switzerland about 38\% - 78\% of the strains causing mastitis are estimated to form penicillinase. Therefore, insufficient dosage in intramammary administration of antibiotics or nonindicated application of dry cow therapy should be avoided.

\section{ACKNOWLDGEMENT}

This study was supported in part with the Federal Funds from Tanta Univ. under contract "Monitoring of environmental pollution of foods of animal origin in ElGharbia and Kafr El-Sheikh Governorates" of code No. 392

\section{REFERENCES}

- Abou-Zaid,A.and El-Sawalhy,A.( 1999):Some studies on mastitis in cattle. Alex.J. Vet. Sci. 15 (1) 23-30.

- Ahmed, H.F. and Azza.M. Deeb ( 2001): Prevalence of subclinical mastitis in dairy cows in Kafr El-Sheikh and El-Gharbia Governorates with special observation to antibiotic sensitivity. $6^{\text {th }}$ Sci. Cong. Egyptian Society for cattle Diseases 4-6 Nov. Assiut, Egypt.

- American Public Health Association “APHA" ( 1993 ): Standard methods for the examination of dairy products 16 th. Ed. APHA Washington, DC .

- Anderson, K. (1989): Therapy for acute Coliform mastitis. Compendium for continuing Education for the Practising Veterinary Surgeon.11(9)1125-1133

- Atherton, H. V. Newlander, J. A. ( 1977 ) : Chemistry and testing of dairy products 4th Ed. The AVI Publishing Co., INC. Westport, Comectict .

- Azza M. Deeb ( 1996): Microbial and chemical monitoring of raw milk and some dairy products as indices for sanitary quality.M.V. Sc.Thesis,Fac.Vet. Med. Tanta. Univ.

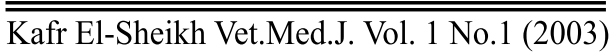


- Bailey.W.R.and Scott,E.C.( 1994 ):Diagnostic Microbiology. 9th Ed. Ellen J. Baron, Lancer R. Peterson and Sydney M. Finegold .The C.V.Mosby Co., Saint Louis .

- Blowey . R, and Edmondson, P .(1995) : Mastitis Control in dairy herds. Diamond Farm Enterprises,box 537,Alexandria Bay Ny 13607,USA.,27:45.

- Bodman, G; Rice,D. and Kubic, D. ( 1988 ): Mastitin matmo1 guidelines.U. S. feed Grains Council .

- Booth. J.M. ( 1996) : Is bovine mastitis being reduced. The XIX World Buiatrics Congress. Edinburgh 8-12 July (Vol.1) British Cattle Vet. Association . 292-295.

- El-Kholy,A.M. and Hosein, H.I. ( 1990); Studies on subclinical mycotic mastitis in cows. Assiut Vet. Med. J. 22 ( 44 ): 111-115.

- Gaddo,V. ;Renata ,P.;Caterina Dalben;Valerio ,B. and Alfonso,Z. (1996): Phenotyic and genotypic characteristics of Staph .aureus strains isolated from clinical and subclinical mastitis. Phenotypic The XIX World Buiatiries Congress.Edinburgh 8-15 July( Vol.1)British Cattle Veterinary Association.

- Hafez, A.M.; Razig, S.A. ; El-Amrousi, S. and Ramadan ,R.O. ( 1984): Studies on mastitis in farm animals in Al-Hasa, I-Analytical studies. Assiut Vet. Med. J. 19 : 140-145.

- Hirsh, D. C. and Zee, Y. C. ( 1999 ): Veterinary Microbiology . Black well Science . Inc .

- Hogan,J. S.; Pankey, J. W. ;Murdough, P. A.and Howard, D. B.(1986) : Survey of bulk tank milk using blood-esculin agar counts.J.Food Prot. 49:990 .

- Ibtisam, E .; Mohamed, O . and Mohamed, G . E . ( 1995 ): The effect of mastitis on milk yield of Friesian cattle in Sudan. J. Egypt.Vet. Med.Ass.55 (1,2): 361 .

- Larry Smith,K.;Tadhunter,D.A and Schoenberger,P.S.(1985): Environm- ental mastitis : causes, Prevelance, prevention.J. Dairy Sci, 68:416.

$\overline{\overline{\text { Kafr El-Sheikh Vet.Med.J. Vol. } 1 \text { No.1 (2003) }}}$ 
- Larry Smith,K.and Hogan,J.S.( 1993): Environmental mastitis. Veterinary Clincs of North America ( food animal practice ) 9:3 P.489-498.

- Larry Smith, K. and Hogan. J.S. ( 1996) : Future prospects for mastitis control. World Association for Buiatrics XIX Congress Edinburgh.

- Logan, E.F. and Gillespie, P.J.( 1996 ): Introducing a national mastitis advisory programme.World Association for Buiatrics XIX Cong. Edinburgh. 322-325.

- Mahmoud, A.A.(1988): Some studies on subclinical mastitis in dairy cattle. Assiut Vet. Med. J. 20 (39) 150-154.

- Nazem, A.M. and Azab, M.H.( 1998 ): Detection of apparently normal milk hv crreenino and renfirmatory methods. 8th Sci. Con.

- Ngeleka, M. ; Adesiyun, A.A. and Romain, H. (1998): Occurrence of selected phenotypic viralence markers and antibiotic resistance of E-coli strains isolates from milk, faeces of dairy cows and water in dairy farms in Trinided. $4^{\text {th }}$ World Congress (Food born Infection and Intoxication) $7-12$ June Berlin. Germany.

- Nickerson S.C.(1993):Preventing new Staphylococcus aureus interamam- mary infection. Vet. Med. 88:368.

- Omyma, Saleh.(1999): Studies on subclinical mastitis in dairy cows in Beni - Suef Governorate . Beni - Suef Vet . Med . J . 9 ( 3 - B ) : $409-415$.

- Pankey, J . W . (1989) : Pre-milking udder hygiene .J. Dairy Sci. 72 (5): 1308 - 1312

- Patil,N.A.; Haraponhalli,M.D.; Mulia,J.A.; Hosmanl,S.V and Pugashetti, B.K. (1995): Comparative study on prevalance and diagnosis of subclinical mastitis in cows and buffaloes.Ind.J. Dairy Sci., 48 (7): 478-479.

- Ramachandrainh, Kumar, K. $\quad S . \quad$ and Srimannarana,O.(1990): Survey of mastitis in pure Jersey herd . Ind. Vet. J. 69 (2) : 103.

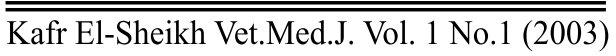


- Refai, M.K. (1988): Mastitis aetiology, diagnosis and control.J.Egypt.Vet . Med . Ass .48 (4): 521 - 545 .

- Saeman,A.I;Verdi,R.J.;Galton,D.M. and Barbano, D.M .(1988): Effect of mastitis on proteolytic activity in bovine milk. J. Dairy. Sci; .71: 505 .

- Schukken.Y.H.;Grommers, F.J.;Vande Geer, D. and Brand,A.(1989): Incidence of clinical mastitis on farms with low somatic cell counts in bulk milk. Vet. Rec. 15; 125 (3) : 60-63.

- Tawfik, M.S.;Nashed,S.M.;Goda, F.F.M.; Samira El-Gibaly ; Farid, A.F. and Nada, S. ( 1984) : Preliminary studies on bacteria recovered from milk of apparently health udders in dairy cattle at ElHaram area with special reference to antibiotic sensitivity. Assiut Vet. Med. J., 12 (23) 91-96.

- Wilson,D.J.;Gonzalez,R.N. and Sear.P.M. (1994):Bulk tank and individual cow milk cultures for detection of contagious mastitis pathogens before adding purchased animals to dairy herds. Pag 3 in Proc.Am.Assoc.Vet. Assoc. Vet. Lab. Diag. Grand Rapids, MI.

- Zatoun,A. M.and Manna, A. M. (1992): Klebsiella nnoumnniso mastitis in dairy cows. Assiut Vet. Med J. 27 ( 54 ) :179

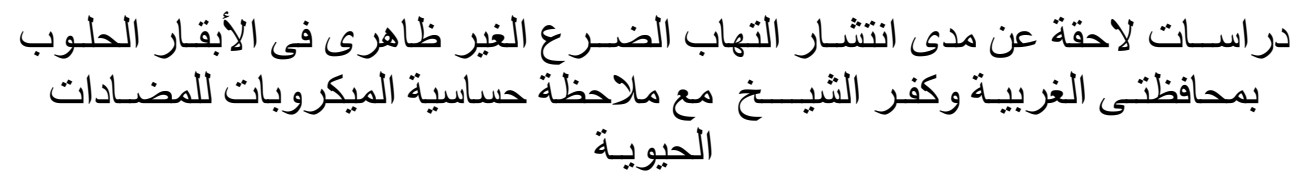

\section{إبراهيم إبراهيم الهوارى -عزة محمود كامل صبيع -ابراهيم محمد أمسان قسم مراقبة الأغذية-كلية الطب البيطرى بكفر الشيخ-جامعة طنطا}

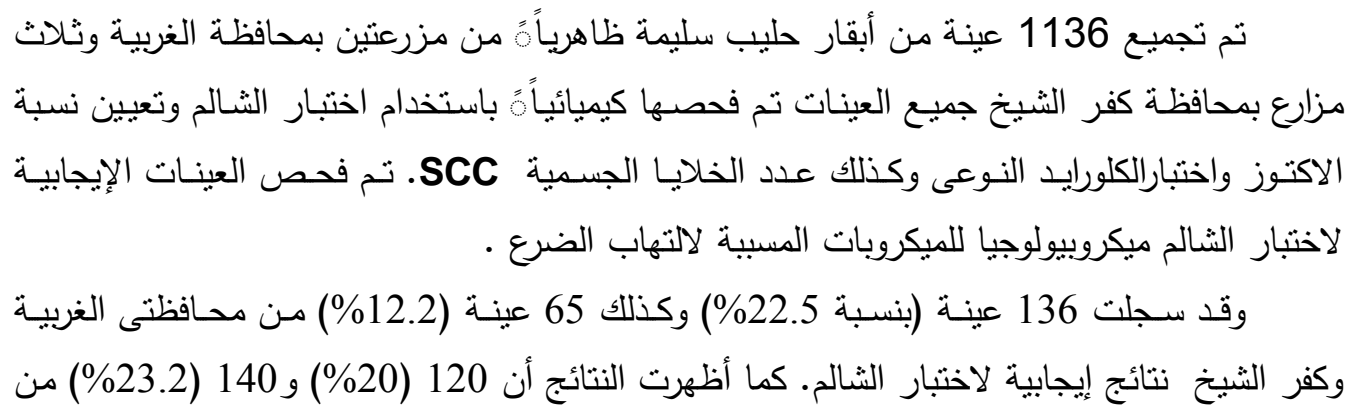

$\overline{\overline{\text { Kafr El-Sheikh Vet.Med.J. Vol. } 1 \text { No.1 (2003) }}}$ 
عينات محافظة الغربية تحتوى على لاكتوز بنسبة أقل من 4.7\% وكلورايد بنسبة أعلى من 0.14\%

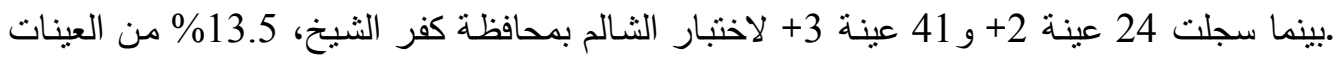
سجلت نسبة لاكتوز اقل من 4.7\% و 22.4\% من العينات سجلت نسبة كلورايد أعلي من

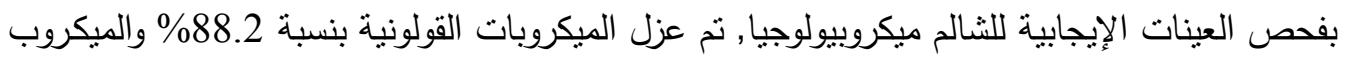
العنقودى بنسبة 26.5\% وميكروب الايشريشيا كولاى بنسبة 14.7\% وذلك من عينات محافظة الغربية بينما لم ينت عزل الميكروب العنقودى الذهبى coagulase+ve وكذلك الميكروب السبحى اجالكتيا.

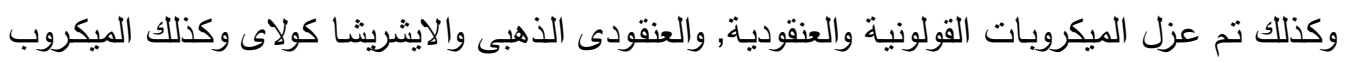

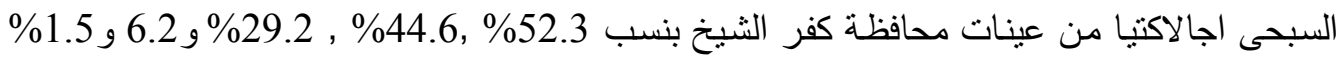

بعد اجراء عد للخلايـا الجسمية للعينـات الإيجابيـة للثـالم , وجد أن العدد يتراوح من 105 على التوالى. إلى 107

$\overline{\overline{\text { Kafr El-Sheikh Vet.Med.J. Vol. } 1 \text { No.1 (2003) }}}$ 